International Journal of Instruction

e-ISSN: 1308-1470 • www.e-iji.net

Article submission code:

20191226134643

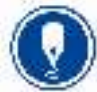

January $2021 \bullet$ Vol.14, No.1

p-ISSN: 1694-609X

pp. 459-474

Received: 26/12/2019

Revision: 03/07/2020
Accepted: 23/07/2020

OnlineFirst: 25/10/2020

\title{
Vietnamese EFL High School Students' Use of Self-Regulated Language Learning Strategies for Project-Based Learning
}

\author{
Thao Quoc Tran \\ Dr., Ho Chi Minh City University of Technology (HUTECH), Vietnam, \\ tq.thao@hutech.edu.vn
}

\section{Tu Ngoc Phan Tran}

Bui Thi Xuan High School, Vietnam, tranphanngoctubtx@gmail.com

It is of importance to foster ESL/EFL students to become more autonomous in their language learning. Project-based learning (PBL) is considered as one of the effective choices for teachers in order to trigger self-regulation among students. However, PBL seems to be still alien to many EFL teachers and students at the high school levels. Within such a context, this study, part of a project, aims at exploring EFL high school students' use of self-regulated language learning (SRLL) strategies for PBL. This study involved 147 EFL high school students from a high school in Vietnam in answering the questionnaire, and forty students of which took part in semi-structured interviews. The quantitative data from questionnaire were analyzed in terms of mean and ANOVA, while qualitative data from interviews were analyzed by the content analysis approach. The findings showed that research participants usually employed SRLL strategies for PBL. Moreover, the group of flexible use of strategies was applied more frequently than other six groups of strategies. Additionally, the frequency of EFL high school students utilized SRLL strategies for PBL similarly was not influenced by their levels of academic study. These preliminary findings are hoped to contribute to a better understanding of the use of SRLL strategies in implementing PBL.

Keywords: EFL high school students, project-based learning, self-regulated language learning strategies, Vietnam, EFL

\section{INTRODUCTION}

Project-based learning (PBL) is regarded as one of the useful and effective ways to enhance learners' self-regulation. Dewey (1959), a pioneer of PBL, confirms that students acquire more in-depth knowledge and skills by implementing and solving meaningful tasks related to their real-life problems. Likewise, PBL is an alternative option for teaching and learning as it encourages students to tackle real-world problems in an effective way (e.g., Helle, Tynjala \& Olkinuora, 2006; Krajcik, Czerniak \& Berger, 1999). Moreover, during the PBL implementation, there appears the demand of learners' regulating own learning, which has underlined self-regulated learning. Jane and

Citation: Tran, T. Q., \& Phan Tran, T. N. (2021). Vietnamese EFL High School Students' Use of SelfRegulated Language Learning Strategies for Project-Based Learning. International Journal of Instruction, 14(1), 459-474. https://doi.org/10.29333/iji.2021.14127a 
Suzie (2013) state that PBL can bring students self-regulation which can entail selfregulated learning strategies.

Realizing the important benefits of PBL in enhancing students' language learning and creating productive environments in which students can improve their learning skills and self-regulation, Ministry of Education and Training of Vietnam has designed the new English textbooks for high school in which projects are embedded. The projects aim to aid EFL high school students to utilize the English language (both knowledge and skills) learned in each unit. Students are required to collaborate with their peers to fulfill and present their projects. It is observed, nonetheless, that how students prepare for projects is still blurred to teachers. Therefore, this case study endeavors to examine the employment of self-regulated language learning (SRLL) strategies for PBL by EFL students at a high school in Vietnam. The research questions to be addressed are as follows:

1. What SRLL strategies are used for PBL by EFL high school students at a high school in Vietnam?

2. Do EFL high school students employ SRLL strategies for PBL differently in terms of grades? If yes, how?

\section{Literature Review}

PBL is variously defined. Markham (2003) defines PBL as "a systematic teaching method that engages students in learning knowledge and skills through an extended inquiry process structured around complex, authentic questions and carefully designed products and tasks" (p.4). Likewise, Savery (2006) states that PBL is a constructivist instructional method because it encourages students to collaborate in groups and improve their self-regulation to solve their real life problems, basing on the rudimental knowledge they have learnt. In short, PBL is a learner-centered approach that triggers students' collaboration, self-regulation and critical thinking skills through experience of solving real-life problems.

Regarding SRLL, Pintrich (2000) is considered self-regulation as the extent to which students identify their learning goals and regulate their cognition, motivations and behavior in an active and constructive process. It is also the process in which learners are in an attempt to control complicate learning activities in their own experience of learning.

SRLL strategies for PBL in this study consist of seven groups, viz. goal setting, planning, self-motivation, attention control, flexible use of strategies, self-monitoring, and self-evaluation.

\section{Goal setting}

Goal setting is an important factor that motivates students to achieve higher academic results. Researchers (e.g., Tran \& Duong, 2013; Winne \& Hadwin, 1998; Wolters, 1998) state that goal planning is considered as the integral element among SRLL strategies because it is standard to regulate student's actions. Nguyen (2014) indicates that it is of essence for students to have the stated goals so that they comprehend and support the learning content not only in their project process but also in the completed 
products. In terms of PBL, when students implemented it correctly and effectively, goal setting becomes the potential to positively long-term influence on their learning.

\section{Planning}

Along with goal setting, planning is necessary to assist students to foster their SRLL. Schunk (2001) clarifies that both goal setting and planning are mutually complementary factors in SRLL. He categorizes planning into three stages, consisting of setting a goal for a task, setting up strategies to reach the goal and determining the time as well as the material resources to attain the goal. Zimmerman (2004) asserts that like goal setting, it is important for students to keep track of the progress by taking notes regularly in this strategy. In a similar vein, Nguyen (2011) mentions that it is imperative for students to have a high degree of planning and organization when they implemented PBL. She adds time frame is an integral factor in planning a project; therefore, students should organize their time effectively.

\section{Self-motivation}

In order to achieve the desired goals or objectives, it is vital for students to take action and self-motivate themselves on their learning. Nguyen (2015) considers motivation as the salient characteristic of PBL in order to solve the students' related problems. Zimmerman (2004) and Corno (1993) highlight self-motivation, whose appearance is when a student independently applies one or more strategies in their learning process in order to achieve a set goal. They find it important for students to control over the learning by themselves and become more autonomous in their learning. Pintrich (2000) highlights that in order to motivate students, teachers should assist learners to master goal orientations, skills or tasks.

\section{Attention control}

Attention control is one of the significant strategies for students to master when they implement PBL as they are equipped with the capacity to select what they have to pay attention to and what they should ignore. As Winne (1995) asserts that so as to selfregulate their learning, students must have an ability to control their attention. He confirms that when applying this strategy, students need to keep their mind out of distractors as well as work in an appropriate learning environment that is conducive to learning. In addition, it is a necessity to provide sufficient time to complete the projects, which includes the adequate time for each separate task in the projects (Nguyen, 2011).

\section{Flexible use of strategies}

When students apply a wide range of suitable strategies into their learning and implementing their projects, it is much easier for them to achieve the desired academic outcomes. According to Paris and Paris (2001), an effective way to help students succeed in their learning process is to implement various learning strategies with different tasks and then adjust and opt the most suitable and effective strategies for the desired goals. Nevertheless, not all the students, especially those who are in the primary levels, have a good choice of learning strategies. Sometimes, it is time-consuming for them to choose the right learning strategies. Therefore, by scaffolding the use of new 
strategies for students, teachers can help students to become more confident to use new strategies better (Winne, 1995).

\section{Self-monitoring}

Self-monitoring is used effectively in learning environment so as to address students' needs and to foster their independence. As Zimmerman (2004) emphasizes in his research, the process of self-monitoring includes aforementioned strategies, which are goal setting, planning, self-motivation, attention control and flexible use of strategies. Furthermore, setting their own learning goals, planning ahead, independently motivating themselves to meet their goals, focusing their attention on the tasks, and utilizing learning strategies to boost their comprehension of material are the factors that help students to self-monitor their learning process. Ryan, Pintrich and Midgley (2001) cite that by doing this, students can develop their learner autonomy. So as to succeed in this strategy, it is of significance for students to make clear outline for the tasks, keep track of the tasks they involve in by using a schedule and adjust them to meet the satisfactory goals or the complete products (Porter, 2002).

\section{Self-evaluation}

It is believed that students become more self-regulated learners when they have abilities to evaluate their learning process independently (Winne \& Hadwin, 1998). Nguyen (2011) acknowledges that it is a necessity that students' projects should be evaluated at the end of the project work. Teachers should provide students with adequate assessment based on clearly defined standards. Furthermore, students are given a chance to revise as well as to reflect the assessment rubric before it is in use. It is essential for students to reflect the language and the subject acquired during the project, to make recommendations for the similar projects in the future and to receive feedback on the language and content learning from the teachers. As a result, students may enhance their learning abilities and achieve better outcomes in the future.

With regard to PBL and SRLL, although numerous studies on SRLL and PBL have been implemented separately, little research has recently concentrated on the relationships between PBL and SRLL. A study by Stefanou, et al. (2013) aimed at discovering the links between students' self-regulation in problem-based learning and PBL. This study was conducted in two private universities in Northeastern United States with seventyseven students and two instructors within two academic years. Data were analyzed by using MSLQ and LCQ. The findings of the study revealed that students who implemented PBL are reported to perceive higher self-regulation in learning. Another research implemented by Asri, et al. (2017) aimed at investigating the influence of PBL strategy and self-regulation on mathematics learning. One finding of the research showed that there appeared mutual relationships and interaction between PBL and selfregulation among junior EFL high school students in accordance with learning Maths. In Vietnamese context, not many studies on the SRLL strategies for PBL have been recently conducted. A significant study was conducted by Nguyen (2017) who investigated the impacts of teaching English language skills using project work on learner autonomy. The participants of the study included fifty students whose major was English language teaching at Can Tho University. Self-assessment questionnaire and 
interviews were utilized to collect and analyze the data. The findings of the study revealed that PBL fostered the students' degree of learner autonomy. Furthermore, other aspects of learner autonomy including self-regulation in learning, self-responsibility and attitudes did not change. All in all, most of the studies above showed that PBL was one of the elements that enhances learners' self-regulation. However, little research focuses on the utilization of SRLL strategies in relation to PBL among EFL high school students.

\section{METHOD}

\section{Research Setting and Participants}

This case study was conducted at a high school in Vietnam. This high school has used new English textbooks designed by Ministry of Education and Training of Vietnam for more than four years. To study in classes with new English textbooks, students were obliged to take an entrance examination, so their English proficiency is rather good. In order to do projects, five or six students were flexibly grouped. They then had to work together in a period of one week to prepare their assigned project and present it orally in class. The number of projects each year students had to do is six to eight out of ten.

The research participants were 147 EFL students purposively chosen from grades 10 , 11, 12 who were using the new English textbooks. Table 1 shows that the participants were from three grades 10,11 , and 12 with the frequency of 49,53 and 45 , respectively. Besides, most of students had learned English for more than eight years $(77.5 \%)$, and $35.4 \%$ of them had extra English classes at English centers.

Table 1

Participants' general information

\begin{tabular}{|c|c|c|c|c|}
\hline \multirow{2}{*}{ No. } & \multirow{2}{*}{ Information } & & \multicolumn{2}{|c|}{$\mathrm{N}=147$} \\
\hline & & & $\mathrm{F}$ & $\%$ \\
\hline \multirow{3}{*}{1} & \multirow{3}{*}{ Grade } & 10 & 49 & 33.3 \\
\hline & & 11 & 53 & 36 \\
\hline & & 12 & 45 & 30.7 \\
\hline \multirow{4}{*}{2} & \multirow{4}{*}{$\begin{array}{l}\text { Number of years' learning } \\
\text { English }\end{array}$} & $>5$ & 0 & 0 \\
\hline & & $5-8$ & 33 & 22.4 \\
\hline & & $<8-10$ & 78 & 53 \\
\hline & & $<10$ & 36 & 24.5 \\
\hline \multirow{2}{*}{3} & \multirow{2}{*}{ Learning at English center } & Yes & 52 & 35.4 \\
\hline & & No & 95 & 64.6 \\
\hline
\end{tabular}

Note: F: Frequency; \%: Percent

As focus group interview was used in this study, 40 students who had answered the questionnaire were purposively invited to participate in semi-structured interviews. An equal proportion for males and females (20 students each) was from three different grades (14 students from grade 10; 13 students from grade 11; 13 students from grade 12).

\section{Research Instruments}

Two instruments, namely questionnaire and semi-structured interview were employed to collect the data. The former which was designed based on the literature review consists 
of 29 closed-ended questions divided into two parts: part A asking respondents' background information; part B measuring SRLL strategy use for PBL. The five-point Likert like scale (never to always) is used for 29 closed-ended questions which are categorized in seven groups (Goal setting: 4 items; Planning: 8 items; Self-motivation: 4; Attention control: 5 items; Flexible use of strategies: 4 items; Self-monitoring: 5 items; Self-evaluation: 3items). The latter includes five main questions to get in-depth information from respondents' SRLL strategy use and cross-check the information gained from the questionnaire.

Both questionnaire and interview questions were translated into respondents' mother tongue (Vietnamese) so that they would not face and language barriers in answering questionnaire and interview questions. A pilot study was carried out to make sure that the questionnaire and semi-structured interview are valid. Cronbach Alpha $\alpha$ of the questionnaire was at .905. This means that the reliability of the questionnaire was high.

\section{Procedures for Data Collection and Analysis}

The data collection was conducted at the end of academic school year 2018-2019, when students had finished their curriculum at school. One hundred and fifty-five copies of questionnaire were administered in person to students in grades 10,11, and 12 at a high school; however, 147 copies of questionnaire were returned. Students spent around 20 minutes completing the questionnaire. For interview, ten groups of four students were invited for informal interview. Each interview lasted from 40 to 45 minutes. All interviews were recorded for later analysis.

With respect to data analysis, quantitative data from the questionnaires were analyzed by using SPSS 21.0 in terms of descriptive statistics and ANOVA. The meaning of the mean scores for the students' SRLL strategy used was interpreted as 1-1.80: never; 1.81-2.60: seldom; 2.61-3.40: sometimes; 3.41- 4.20: usually; 4.21 - 5.00: always. Qualitative data were analyzed by using the content analysis approach. The recordings were transcribed carefully. All 40 interviewees were coded from S1 to S40. In order to make data analysis reliable, two researchers were invited to re-analyze three random pieces of qualitative data, and the agreed findings had to reach from $95 \%$.

\section{FINDINGS}

\section{EFL High School Students' SRLL Strategies Use for PBL}

As observed in Table 2, the frequency of using SRLL strategies for PBL is rather high $(\mathrm{M}=3.62$; SD: .46), which reveals that students usually used SRLL strategies. Flexible use of strategies for PBL was determined as the most frequently used strategy by EFL high school students (Group 5: $\mathrm{M}=3.88 ; \mathrm{SD}=.63$ ), followed by Planning (Group 2: $\mathrm{M}=3.66 ; \mathrm{SD}=.61$ ), Attention control (Group 4: $\mathrm{M}=3.62 ; \mathrm{SD}=.63$ ), Self-monitoring (Group 6: $\mathrm{M}=3.58 ; \mathrm{SD}=.61$ ) and Goal setting (Group 1: $\mathrm{M}=3.57 ; \mathrm{SD}=.74$ ). The two least frequently used strategies that EFL high school students applied were Selfmotivation (Group 3: $\mathrm{M}=3.51 ; \mathrm{SD}=.64$ ) and self-evaluation (Group 7: $\mathrm{M}=3.51$; $\mathrm{SD}=.80$ ). To sum up, EFL high school students tended to employ flexible strategies usually when they did a project. 
Table 2

$\underline{\text { SRLL strategies use in PBL among EFL high school students }}$

\begin{tabular}{llll}
\hline \multirow{2}{*}{ No. } & \multirow{2}{*}{ SRLL strategies } & $\mathrm{N}=147$ & \\
\cline { 3 - 4 } & & $\mathrm{M}$ & $\mathrm{SD}$ \\
\hline 1 & Goal setting & 3.57 & .74 \\
\hline 2 & Planning & 3.66 & .61 \\
\hline 3 & Self-motivation & 3.51 & .64 \\
\hline 4 & Attention control & 3.62 & .63 \\
\hline 5 & Flexible use of strategies & 3.88 & .63 \\
\hline 6 & Self-monitoring & 3.58 & .61 \\
\hline 7 & Self-evaluation & 3.51 & .80 \\
\hline Total & & 3.62 & .46 \\
\hline
\end{tabular}

Note: M: mean; SD: Standard deviation

Specifically, Table 3 shows that the frequency of using goal setting strategies for PBL among EFL high school students was quite high $(\mathrm{M}=3.57 ; \mathrm{SD}=.74)$. Students tended to "make an action plan for the projects" (item 2: $\mathrm{M}=3.83 ; \mathrm{SD}=.93$ ) more often than the others two strategies items in goal setting. It was followed by "set[ting] a goal before implementing the projects" (item 1: $\mathrm{M}=3.56 ; \mathrm{SD}=1.06$ ) and "review[ing] goals regularly" (item 3: $\mathrm{M}=3.31$; $\mathrm{SD}=1.03$ ). It can be understood that $\mathrm{t} E \mathrm{EL}$ high school students usually created plans and set goals for their projects when they conducted projects. However, they sometimes examined the goals carefully again and again during project implementation.

Table 3

The frequency of using goal setting strategies for PBL among EFL high school students

\begin{tabular}{llll}
\multirow{2}{*}{ No. } & \multirow{2}{*}{ Goal setting } & \multicolumn{2}{c}{$\mathrm{N}=147$} \\
\cline { 3 - 4 } & & $\mathrm{M}$ & $\mathrm{SD}$ \\
\hline 1 & set a goal before implementing the projects & 3.56 & 1.06 \\
\hline 2 & make an action plan for the projects & 3.83 & .93 \\
\hline 3 & review goals regularly & 3.31 & 1.03 \\
\hline Total & & 3.57 & .74 \\
\hline
\end{tabular}

Regarding the interview data, nearly half of the EFL high school students supposed that goal setting was the most important strategy for PBL. The reasons why they considered this strategy as the most important strategy varied. Some of the obvious examples for the reasons are:

In my opinion, goal setting is the most important SRLL strategy as it is the primary strategy of all steps. (S1)

I think goal setting was an oriental step for the other next steps; therefore, it is the most important SRLL strategy. (S6)

From my point of view, Goal Setting is the most important SRLL strategy. Thanks to Goal Setting, I know what I have to do and how I can process my project effectively. (S20)

Planning strategies for PBL used by EFL high school students was evaluated by five items. As shown in Table 4, students tended to use planning strategy more often 
$(\mathrm{M}=3.66 ; \mathrm{SD}=.61)$. Among the five items students frequently "discuss[ed] to find the topics of the projects" (item 5: $\mathrm{M}=3.90 ; \mathrm{SD}=.92$ ), "discuss[ed] to find suitable strategies for [their] projects (item 7: $\mathrm{M}=3.85 ; \mathrm{SD}=1.03$ ) and "determine[d] an amount of time to finish the projects" (item $6: \mathrm{M}=3.83 ; \mathrm{SD}=1.11$ ). These items were comparatively higher than the others. "Set[ting] a goal for each task of the projects" (item 4: $M=3.56$; $\mathrm{SD}=1.06)$ was followed with lower frequency of using. Nevertheless, students sometimes "[took] note to track the progress of the projects" (item 8: $M=3.17$; $\mathrm{SD}=1.23$ ). It can be interpreted that EFL high school students frequently had a discussion to opt for the topics of the projects, the time to finish the projects as well as the appropriate strategies for the project. However, they did not have an often habit to track the project progress by taking notes regularly.

Table 4 The frequency of using Planning strategies for PBL among EFL high school students

\begin{tabular}{|c|c|c|c|}
\hline \multirow{2}{*}{$\begin{array}{l}\text { No } \\
\text {. } \\
\end{array}$} & \multirow{2}{*}{ Planning } & \multicolumn{2}{|c|}{$\mathrm{N}=147$} \\
\hline & & $\mathrm{M}$ & SD \\
\hline 4 & set a goal for each task of the projects & 3.56 & 1.06 \\
\hline 5 & discuss to find the topics of the projects & 3.90 & .92 \\
\hline 6 & determine an amount of time to finish the projects & 3.83 & 1.11 \\
\hline 7 & discuss to find suitable strategies for my projects & 3.85 & 1.03 \\
\hline 8 & take note to track the progress of the projects & 3.17 & 1.23 \\
\hline Tota & & 3.66 & 61 \\
\hline
\end{tabular}

The findings from the interview data indicated that many EFL high school students agreed that planning strategies for PBL was important when they did projects. Discussing about the choice of planning as the most important strategy, EFL high school students provided different reasons. Some of their responses are as follows:

Among the seven SRLL strategies, I believe that planning is the most vital SRLL strategy because it is considered as the instructional guidelines for me to follow during the project implementation. (S17)

It is significant for me to have a clear framework to follow; therefore, planning is my choice for the most important strategy. (S21)

From my perspectives, Planning is the most essential SRLL strategy because helps me to scaffold my projects step by step. (S38)

Self-motivation strategies for PBL among EFL high school students was measured by four items. The students, as seen in Table 5, often adopted this strategy in the process of doing their projects $(\mathrm{M}=3.51 ; \mathrm{SD}=.64)$. Interestingly, the mean scores of the two items including "get[ting] feedback on the performance" (item 10: M=3.70; SD.94) and "expand[ing] the ability to do the projects" (item 11: M=3.70; SD.94) were equal. The third item related to mean scores value was "find[ing] new skills to do the projects (item 9: $\mathrm{M}=3.43 ; \mathrm{SD}=.83$ ). The least frequency item of using self-motivation strategy in $\mathrm{PBL}$ was "tak[ing] time to reflect the work" (item 12: $\mathrm{M}=3.22 ; \mathrm{SD}=1.06$ ). To conclude, whereas EFL high school students usually received feedback on their own performance, promoted the capacity for implementing the projects and explored the new skills so as to do the projects, they occasionally spent their time on reflecting the activities in the 
projects. Moreover, among the seven strategies mentioned in this study, self-motivation strategies for PBL was the least used by EFL high school students.

Table 5

The frequency of using self-motivation strategies for PBL among EFL high school students

\begin{tabular}{|c|c|c|c|}
\hline \multirow[t]{2}{*}{ No } & \multirow{2}{*}{ Self-motivation } & \multicolumn{2}{|c|}{$\mathrm{N}=147$} \\
\hline & & M & SD \\
\hline 9 & find new skills to do the projects & 3.43 & $\begin{array}{l}.83 \\
\end{array}$ \\
\hline 10 & get feedback on the performance & 3.70 & .94 \\
\hline 11 & expand the ability to do the projects & 3.70 & .94 \\
\hline 12 & take time to reflect the work & 3.22 & 1.06 \\
\hline Tot & & 3.51 & .64 \\
\hline
\end{tabular}

Qualitative data revealed that only two out of $40 \mathrm{EFL}$ high school students agreed that self-motivation strategies for PBL played an integral part during project implementation. Some obvious examples of the reasons for their choice are mentioned below:

In terms of the most important strategy, my selection is self-motivation as it gives me enthusiasm to do my projects. (S12)

I think the most integral strategy is self-motivation as it boosts my energy and my ability to do my projects. (S25)

Five items were to evaluate the frequency of utilizing attention control strategies for PBL among EFL high school students. As shown in Table 6, students applied this strategy rather frequently $(\mathrm{M}=3.62 ; \mathrm{SD}=.63)$. Among the five items mentioned in this strategy, the most often item that students used was to "seek a suitable learning environment when doing the projects" (item 14: $\mathrm{M}=3.88 ; \mathrm{SD}=.89$ ), followed by "keep[ing] mind out of distractors during projects implementation" (item 15: $\mathrm{M}=3.75$; $\mathrm{SD}=1.03$ ) and "spend[ing] focused time on each task" (item 17: $\mathrm{M}=3.70 ; \mathrm{SD}=.98$ ). However, students spent less time on "shorten[ing] the time for each task" (item 16: $\mathrm{M}=3.48 ; \mathrm{SD}=.96$ ) and "select[ing] the order of assignments" (item 13: $\mathrm{M}=3.33$; $\mathrm{SD}=1.13$ ). In short, EFL high school students usually found out appropriate environment for learning and had a tendency to get rid of distractors when they implemented projects. However, it was noticed that they sometimes had a habit of choosing the order of assignments.

Table 6

The frequency of using Attention control strategies for PBL among EFL high school students

\begin{tabular}{llll}
\hline \multirow{2}{*}{$\begin{array}{l}\text { Attention control } \\
\text { • }\end{array}$} & \multicolumn{2}{c}{$\mathrm{N}=147$} \\
\cline { 3 - 4 } 13 & select the order of assignments & $\mathrm{M}$ & $\mathrm{SD}$ \\
\hline 14 & seek a suitable learning environment when doing the projects & 3.33 & 1.13 \\
\hline 15 & keep mind out of distractors during projects implementation & 3.88 & .89 \\
\hline 16 & shorten the time for each task & 3.75 & 1.03 \\
\hline 17 & spend focused time on each task & 3.48 & .96 \\
\hline Total & & 3.70 & .98 \\
\hline
\end{tabular}


The qualitative data showed that five out of $40 \mathrm{EFL}$ high school students expressed their agreement that the most significant strategy in SRLL strategies was Attention control. Here are some apparent examples of the students' reasons:

From my viewpoint, attention control is the most important SRLL strategy because it shortens the time to do the projects. When I pay more attention to my projects, I spend less time to complete it. (S7)

I believe that attention control helps me to choose the order of assignment in priority, so I consider it as the most important strategies. (S23)

Compared with the other strategies, the frequency of Flexible use of strategies for PBL with four items was comparatively higher than the other strategies $(\mathrm{M}=3.88 ; \mathrm{S}=.63)$. Table 7 shows that EFL high school students usually "select[ed] effective strategies for each project" (item 18: $\mathrm{M}=3.97 ; \mathrm{SD}=.93$ ) and "use[d] appropriate strategies for every member in the group" (item 20: $\mathrm{M}=3.97 ; \mathrm{SD}=.87$ ) with the same mean scores. Also, they chose "appropriate strategies for each project" frequently (item 19: $M=3.92$; $\mathrm{SD}=.93)$. The least frequent item they used in Flexible use of strategies was "apply[ing] different learning strategies for each project" (item 21: $\mathrm{M}=3.68$; $\mathrm{SD}=.96$ ). In summary, the frequency of flexible use of strategies for PBL was relatively high. EFL high school students had a tendency of selecting appropriate and effective strategies for doing projects and adopted a myriad of learning strategies for each project as well as for each member in the group.

Table 7

The frequency of using Flexible use of strategies for PBL among EFL high school students

\begin{tabular}{llll}
\hline \multirow{2}{*}{ No. } & \multirow{2}{*}{ Flexible use of strategies } & \multicolumn{2}{c}{$\mathrm{N}=147$} \\
\cline { 3 - 4 } & & $\mathrm{M}$ & $\mathrm{SD}$ \\
\hline 18 & choose effective strategies for each project & 3.97 & .93 \\
\hline 19 & choose appropriate strategies for each project & 3.92 & .98 \\
\hline 20 & use appropriate strategies for every member in the group & 3.97 & .87 \\
\hline 21 & apply different learning strategies for each project & 3.68 & .96 \\
\hline Total & & 3.88 & .63 \\
\hline
\end{tabular}

Qualitative data showed that five out of 40 EFL high school students believed that this strategy was of the crucial strategy that they had to master when they conducted their projects. Two of the examples are as follows:

It is of importance to apply different strategies for my projects and Flexible use of strategies is my selection because it helps me know how to choose the appropriate strategies for my projects. (S8)

Thanks to Flexible use of strategies, I know how to select the effective strategies for my projects; therefore, I think it is the most important strategy. (S14)

Self-monitoring strategies for PBL with five items was another group of strategies that EFL high school students applied when they implemented PBL. The frequency of using self-monitoring strategies for PBL among EFL high school students, as regarded in 
Table 8, was not as high as expected $(\mathrm{M}=3.58 ; \mathrm{SD}=.85)$. The two most frequent items in self-monitoring strategies for PBL that EFL high school students usually applied when they implemented PBL were "us[ing] suitable learning strategies to facilitate the understanding of lessons" (item $26: \mathrm{M}=3.85 ; \mathrm{SD}=.85$ ) and "focus[ing] their attention on the task at hand" (item 25: $\mathrm{M}=3.77 ; \mathrm{SD}=.89$ ). The two next items in the list were "set[ting] learning goals" (item 22: $\mathrm{M}=3.54 ; \mathrm{SD}=1.06$ ) and "mak[ing] an outline for each step in the projects" (item 23: $\mathrm{M}=3.51 ; \mathrm{SD}=1.04$ ). The item that students sometimes utilized when they self-monitored their PBL was "us[ing] a self-monitoring schedule for the projects" (item 24: $\mathrm{M}=3.26 ; \mathrm{SD}=1.02$ ). In brief, by monitoring their own study, EFL high school students usually utilized appropriate learning strategies to comprehend their lesson possibly and easily. Furthermore, they paid more attention to the tasks that needed to be completed in advance. They also set their learning goals before they did their projects as well as made an outline for each step in the projects rather often. Nevertheless, they occasionally prepared a self-monitoring schedule and used it often during the project implementation.

Table 8

The frequency of using Self-monitoring strategies for PBL among EFL high school students

\begin{tabular}{llll}
\hline \multirow{2}{*}{ No. } & Self-monitoring & $\mathrm{N}=147$ \\
\cline { 3 - 4 } 22 & set learning goals & $\mathrm{M}$ & $\mathrm{SD}$ \\
\hline 23 & make an outline for each step in the projects & 3.54 & 1.06 \\
\hline 24 & use a self-monitoring schedule for the projects & 3.51 & 1.04 \\
\hline 25 & focus their attention on the tasks at hand & 3.26 & 1.02 \\
\hline 26 & use suitable learning strategies to facilitate the understanding of lessons & 3.77 & .892 \\
\hline Total & & 3.58 & .855 \\
\hline
\end{tabular}

Note: M: mean; SD: Standard deviation

Qualitative data showed that two EFL high school students agreed that Self-monitoring strategies for PBL was the most vital strategy in implementing PBL process. This number was as equal as that of Self-motivation strategy. One of the students' ideas can be described as follows:

In my opinion, the most important strategy when implementing PBL is Self-monitoring because I need to monitor progress towards the goals of my progress and have suitable adjustment if necessary. (S19)

Observed from Table 9, EFL high school students used self-evaluation strategies for PBL relatively often $(\mathrm{M}=3.51 ; \mathrm{SD}=.80)$. Among the three items, students "selfevaluated the finished projects" (item 28: $\mathrm{M}=3.58 ; \mathrm{SD}=.93$ ) more often than the other two, which were "mak[ing] adjustments for similar tasks in the future" (item 29: $\mathrm{M}=3.50 ; \mathrm{SD}=1.09$ ) and "self-evaluat[ing] the learning process independently" (item 27: $\mathrm{M}=3.45 ; \mathrm{SD}=.95$ ). To summarize, the use of self-evaluation strategies for PBL and selfmonitoring strategies for PBL among EFL high school students were of the two least utilized SRLL strategies mentioned in this study. However, they showed their frequency 
of evaluating their own learning process as well as their finished products. More importantly, they usually adjusted their similar tasks in the next projects in the future.

Table 9

The frequency of using Self-evaluation strategies for PBL among EFL high school students

\begin{tabular}{llll}
\hline \multirow{2}{*}{ No } & \multirow{2}{*}{ Self-evaluation } & \multicolumn{2}{c}{$\mathrm{N}=147$} \\
\cline { 3 - 4 } 27 & self-evaluate the learning process independently & $\mathrm{M}$ & $\mathrm{SD}$ \\
\hline 28 & self-evaluate the finished projects & 3.45 & .95 \\
\hline 29 & make adjustments for similar tasks in the future & 3.50 & .93 \\
\hline Total & & 3.51 & 1.09 \\
\hline
\end{tabular}

Note: : mean; SD: Standard deviation

The interview data also showed that self-evaluation strategies for PBL along with attention control strategy and flexible use of strategies had the same number of EFL high school students with five out of 40 students who agreed that these strategies were the integral strategies for them when they did projects. Here is an example:

I can use self-evaluation strategy to evaluate my own projects, so it is an important strategy. (S28)

\section{Differences in EFL High School Students' SRLL Strategies Use For PBL In Terms Of Grades}

The results in Table 11 indicate that EFL high school students employed SRLL strategies for PBL in a similar way $(\mathrm{F}=1.587 ; \mathrm{p}=.208)$. Regarding seven groups of SRLL strategies, there were no significant differences in SRLL strategies for PBL among students (Goal setting: $\mathrm{F}=.492, \mathrm{p}=.612$; Planning: $\mathrm{F}=1.095, \mathrm{p}=.337$; Self-motivation: $\mathrm{F}=3.575, \mathrm{p}=.801 ;$ Attention control: $\mathrm{F}=.072, \mathrm{p}=.930$; Flexible use of strategies: $\mathrm{F}=$ 1.539, $\mathrm{p}=.218$; Self-monitoring: $\mathrm{F}=.933, \mathrm{p}=.396$; Self-evaluation: $\mathrm{F}=.390, \mathrm{p}=.678)$. This means that students' levels of academic study did not affect their SRLL use for PBL significantly.

Table 11

(One-way ANOVA) Differences in students' attitudes toward PBL in terms of grades

\begin{tabular}{llllll}
\hline \multirow{2}{*}{ Variables } & \multirow{2}{*}{$\mathrm{F}$} & \multirow{2}{*}{ Sig. } & Grade 10 & Grade 11 & Grade 12 \\
\cline { 5 - 6 } & & & $\mathrm{M}(\mathrm{SD})$ & $\mathrm{M}(\mathrm{SD})$ & $\mathrm{M}(\mathrm{SD})$ \\
\hline 1. Goal setting & .492 & .612 & $3.56(.77)$ & $3.53(.78)$ & $3.68(.63)$ \\
\hline 2. Planning & 1.095 & .337 & $3.77(.64)$ & $3.59(.60)$ & $3.69(.60)$ \\
\hline 3. Self-motivation & 3.575 & .801 & $3.62(.58)$ & $3.37(.72)$ & $3.68(.41)$ \\
\hline 4. Attention control & .072 & .930 & $3.66(.58)$ & $3.61(.69)$ & $3.62(.57)$ \\
\hline 5. Flexible use of strategies & 1.539 & .218 & $3.94(.65)$ & $3.79(.66)$ & $4.01(.52)$ \\
\hline 6. Self-monitoring & .933 & .396 & $3.67(.61)$ & $3.52(.60)$ & $3.64(.62)$ \\
\hline 7. Self-evaluation & .390 & .678 & $3.53(.94)$ & $3.46(.79)$ & $3.60(.64)$ \\
\hline SRLL strategies & 1.587 & .208 & $3.6(.49)$ & $3.56(.47)$ & $3.70(.38)$ \\
\hline
\end{tabular}

*The mean difference is significant at the .005 level (2-tailed) Note: M: Mean; S.D: Standard Deviation 


\section{DISCUSSIONS}

This study has indicated some significant findings. Firstly, it was found that EFL high school students usually applied SRLL strategies for PBL on a general basis. Regarding seven groups of SRLL strategies for PBL, students were found to employ Flexible use of strategies most, followed by Planning, Attention control, self-monitoring, Goal setting, Self-motivation, and Self-evaluation. One of the possible explanations for this may be that research participants had to do many projects, so they were quite experienced in doing projects (e.g., volunteer work in the neighbourhood, a plan to help someone in the community, staying healthy). That may be the reason why they prioritized using strategies for on choosing effective and appropriate methods for projects and planning for conducting projects. Moreover, research participants had to allocate from one to three hours per day to self-study, which may give more explanation why they prioritized Flexible use of strategies for PBL. This finding is in the same line with Paris and Paris's (2001) perspectives that indicate that learners preferred selecting appropriate and effective strategies for projects.

Regarding goal setting strategies for PBL, which plays a crucial factor in SRLL strategies for PBL (e.g., Winne \& Hadwin, 1998; Wolters, 1998). The finding indicated that EFL high school students often utilized this strategy. Also, they usually set goals and created plans for their projects in advance, but they sometimes examined the goals repeatedly during project implementation. For example, when students were assigned to do a project on a family life of students in class. They first had to set the goals and outline what to do. During the project, they needed to review what had been done. Zimmerman (2004) claims that it is an effective way for students to track their progress when they do their projects. When it comes to planning strategies for PBL, EFL high school students often used this strategy for PBL because planning is one of the crucial strategies for students when they did projects (e.g., Nguyen, 2011; Schunk, 2001). Zimmerman (2004) highlights the essence of taking notes to keep track their project progress regularly; nevertheless, students in this study occasionally carried out it. On the subject of self-motivation strategies for PBL, although Nguyen (2015), Zimmerman (2004) and Corno (1993) emphasize this strategy as the salient characteristic of PBL to trigger student's independence in SRLL, EFL high school students utilized selfmotivation strategies for PBL the least frequently among the seven strategies listed in this study. Like the goal setting and planning strategies for PBL, while students spent more time receiving feedback on their own performance, promoting the capacity for implementing the projects and exploring the new skills to do the projects, they sometimes reflected the tasks in the projects. Regarding attention control strategies for PBL, the findings of this study showed that EFL high school students applied this strategy into doing their projects rather frequently. In the same line with Zimmerman's (2004) confirmation of the significance of study environment, EFL high school students usually selected an appropriate environment for implementing PBL, in which they avoided distractors from learning. In her study, Nguyen (2011) highlighted the adequate the time for doing projects. The findings of this study showed that EFL high school students usually shortened their time and spent focused time for each task. In terms of self-monitoring strategies for PBL, EFL high school students utilized this strategy when 
they implemented PBL rather usually as Zimmerman (2004) stated the importance of this strategy along with the other SRLL strategies for PBL, consisting of Goal setting, Planning, Self-motivation, Attention Control and Flexible use of strategies. It was observed that when students did projects, they did not apply the same strategies for PBL. They used SRLL for PBL flexibly. For example, as for project of finding how a city/country has undergone urbanization, students set goals, planned what to do and sought information from internet. However, regarding the project of conducting a survey on students' green lifestyle, students set goals, planned the tasks, and self-motivated in doing that project. Another finding is that students usually applied suitable learning strategies to understand their lesson easily, which fostered students' self-regulation as Ryan, Pintrich and Midgley (2001) asserted in their study. Moreover, students set their learning goals before they frequently did their projects as well as made an outline for each step in the projects, which partially confirmed Porter's (2002) findings in his previous research. EFL high school students; however, they sometimes took advantage of self-monitoring schedule and used it when conducting their projects. The last selfevaluation strategies for PBL is the one EFL high school students applied rather frequently. The findings confirmed the results in previous studies by Winne and Hadwin (1998) and Schraw and Moshman (1995). Nonetheless, this strategy was least used among the seven strategies. The finding showed a good sign that students began to evaluate their own learning process and their complete products. Also, they retained abilities to assess and adjust their similar tasks in the future projects. For instance, while doing a project of a famous person, students had to check whether the tasks had been correctly done or not by themselves so that they could adjust them.

The second major finding is that SRLL strategy use for PBL was not significantly influenced by their levels of academic study. This may be explained by the fact that EFL high school students in this study were instructed substantially how to conduct a project when they were first assigned projects. Although the results showed that $12^{\text {th }}$ grade students employed SRLL strategies more than their $10^{\text {th }}$ and $11^{\text {th }}$ students, the frequency was not significantly different. Therefore, it may be claimed that EFL students utilize SRLL strategies for PBL similarly regardless the levels of academic study.

\section{CONCLUSION}

The results of this study shed light on the SRLL strategies for PBL among Vietnamese EFL high school students. The findings of the study showed that the frequency of SRLL strategies that EFL high school students used when they carried out PBL was relatively high. Among the seven SRLL strategies for PBL mentioned in this study, the most frequently used strategy by EFL high school students belonged to flexible use of strategies, followed by planning, attention control, self-monitoring and goal setting. Self-motivation and self-evaluation were the two least frequently used strategies that EFL high school students utilized when implementing projects. Additionally, students used SRLL strategies for PBL similarly regardless of their levels of academic study.

As for the pedagogical implications, the results of the study highlight the importance of SRLL strategies in PBL. In order to apply SRLL strategies effectively into PBL, it is of essence for students to practise PBL more frequently at schools. Tran and Tran (2019) 
state that PBL should become a compulsory activity at schools so that students have positive attitudes towards PBL, and teachers and students should change their traditional learning roles although it seems to be a challenging task (Tran, 2012). It is vital for students to create a good habit to self-regulate their PBL. Furthermore, training courses of SRLL strategies should be taken for both teachers and students in order that they can apply them flexibly and practically.

\section{REFERENCES}

Asri, D. N., Setyosari, P., Hitipeuw, I., \& Chusniyah, T. (2017). The Influence of Project-based Learning Strategy and Self-regulated Learning on Academic Procrastination of Junior High School Students' Mathematics Learning. American Journal of Educational Research, 5(1), 88-96.

Corno, L. (1993). The Best-laid plans: Modern conceptions of volition and educational research. Educational Researcher, 22, 14-22.

Dewey, J. (1959). Dewey on education. New York: Teachers College Press.

Helle, L, Tynjala, P., \& Olkinuora, E (2006). Project-based learning in post-secondary education - theory, practice and rubber sling shots. Higher Education, 51, 287-314.

Jane, K., \& Suzie, B. (2013). Thinking through Project-based learning. Guiding Deeper Inquiry. Thousand Oaks, Calif: Corwin Press.

Krajcik, J. S., Czerniak, CM \& Berger, CF (1999). Teaching science: a project-based approach. New York: McGraw-Hill College.

Markham, T. (2003). Project-based learning handbook (2nd ed.). Novato, CA: Buck Institute for Education.

Nguyen, T. V. L. (2011). Project-based learning in teaching English as a foreign language. VNU Journal of Science, Foreign Languages, 27, 140-146.

Nguyen, V. K. (2015). Towards Improving ESP Teaching/Learning in Vietnam's Higher Education Institutions: Integrating Project-Based Learning into ESP Courses. International Journal of $\quad$ Languages, Literature and Linguistics, 1(4), 227-232.

Nguyen, V. L. (2017). Promoting learner autonomy: Lesson from using project work as a supplement in English skills courses. Can Tho University Journal of Science, 7, 118-125.

Paris, S. G., \& Paris, A. H. (2001). Classroom applications of research on self-regulated learning. Educational Psychologist, 36, 89-91.

Pintrich, R. R. (2000). The role of goal orientation in self-regulated learning. In M. Boekaerts, P. R. Pintrich \& M. Zeidner (Eds.), Handbook of self- regulation (pp. 451 501). San Diego, CA: Academic Press.

Porter, L. (2002). Cognitive skills. In L. Porter (Ed.), Educating young children with special needs (pp. 1 91-209). Crow's Nest, Australia: Allen \& Unwin. 
Ryan, A. M., Pintrich, P. R., \& Midgley, C. (2001). Avoiding seeking help in the classroom: Who and why? Educational Psychology Review, 13, 93-114.

Savery, J. R. (2006). Overview of problem-based learning: Definitions and distinctions. Interdisciplinary Journal of Problem-based Learning, 1(1), 3.

Schraw, G., \& Moshman, D. (1995). Metacognitive theories. Educational Psychology Review, 7, 351-371.

Schunk, D. H. (2001). Social cognitive theory and self-regulated learning. In Zimmerman, B. J., \& Schunk, D. H. (Eds.) Self-regulated Learning and Academic Achievement: Theoretical Perspectives. Mahwah, NJ. Lawrence Erlbaum Associates.

Stefanou, C., Stolk, J. S., Olin, F. W., Prince, M., Chen, J. C. \& Lord, S. M. (2013). Self- regulation and autonomy in problem- and project-based learning environments. Active Learning in Higher Education, 14(2), 109-122.

Tran, P. N. T., \& Tran, Q. T. (2019). The Important Roles of Project-based Learning in Teaching English to High School Students. Proceedings of the $7^{\text {th }}$ OPENTESOL International Conference 2019, 279-294.

Tran, Q. T. (2012). Language Learning Strategies in Foreign Language Teaching and Learning. Japan TESOL Journal, 3.

Tran, Q. T., \& Duong, M. T. (2013). The attitudes towards English language learning and use of self-regulated learning strategies among college non-English majors. International Journal of Scientific and Research publications, 3(7), 1-8.

Winne, P. H. (1995). Inherent details in self-regulated learning. Educational Psychologist, 30, 173-188.

Winne, P. H., \& Hadwin, A. F. (1998). Studying as self-regulated learning. In D. J. Hacker \& J. Dunlosky (Eds.), Metacognition in educational theory and practice, The educational psychology series. Mahwah, NJ: Erlbaum.

Wolters, C. (1998). Self-regulated learning and college students' regulation of motivation. Journal of Educational Psychology, 90, 224-235.

Zimmerman, B. J. (2004). Sociocultural influence and students' development of academic self-regulation: A social-cognitive perspective. In D. M. McInerney \& S. Zimmerman, B. J. (2008). Goal setting: A key proactive source of academic selfregulation. In D. H. Schunk \& B. J. Zimmerman (Eds.), Motivation and self-regulated learning: Theory, research, and applications. New York: Lawrence Erlbaum. 